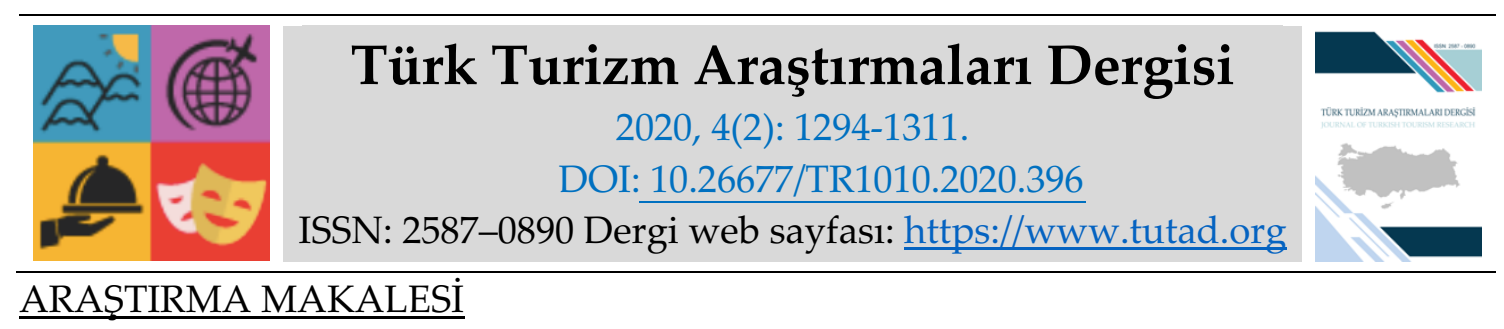

\title{
Konaklama İşletmelerinde Algılanan Atmosferin Müşteri Tatminine Etkisi: Kuşadası Örneği*
}

Arş. Gör. H. Erhan ALTUN, Aydın Adnan Menderes Üniversitesi, Turizm Fakültesi, Aydın, eposta: erhan.altun@adu.edu.tr ORCID: https://orcid.org/0000-0002-9704-5293

Dr. Öğr. Üyesi Tuğrul AYYILDIZ, Aydın Adnan Menderes Üniversitesi, Turizm Fakültesi, Aydın, e-posta: tayyildiz@adu.edu.tr

ORCID: https://orcid.org/0000-0001-6332-975X

Öz

Çalışmanın amacı konaklama işletmelerinde bulunan atmosfer unsurlarının bu işletmelerden hizmet satın alan müşterilerin tatmin düzeyleri üzerindeki etkilerinin incelenmesidir. Çalışmada nicel araştırma yaklaşımı benimsenmiş, konaklama işletmelerinde anket formları ile yüz yüze toplanan veriler korelasyon, regrasyon ve parametrik olmayan istatistiksel testler ile analiz edilmiştir. Analizler sonucunda algılanan atmosfer ve müşteri tatmini arasında \%34.4 oranında pozitif yönlü bir ilişki bulunmuştur. Algılanan atmosfer boyutlarından her birinin müşteri tatmini boyutlarından en az üç tanesini etkilediği görülmüştür. Algılanan atmosferin genel içsel değişkenler boyutunun \%40.9 ile müşteri tatmininin fiziksel özellikler boyutu üzerinde en yüksek etkiye sahip olduğu görülmüştür. En düşük etki (\%12.8) ise algılanan atmosferin çalışanlar ve hijyenle ilgili boyutu ile müşteri tatmininin güven boyutu arasındadır. Atmosfer algılamalarında devamlı müşterilerin sıralar ortalamasının yeni müşterilere göre daha yüksek olduğu sonucu elde edilmiştir. Öte yandan müşteri tatmininin demografik değişkenlerden etklilenmediği bulgulanmıştır.

* Aynı başlıklı yüksek lisans tezinden uyarlanmıştır.

Anahtar Kelimeler: Atmosfer, Kuşadası, Müşteri Tatmini

Makale Gönderme Tarihi: 24.12.2019

Makale Kabul Tarihi: 03.04.2020

\section{Önerilen Atıf:}

Altun, H. E. ve Ayyıldız, T. (2020). Konaklama İşletmelerinde Algılanan Atmosferin Müşteri Tatminine Etkisi: Kuşadası Örneği, Türk Turizm Araştırmaları Dergisi, 4(2): 1294-1311.

(c) 2020 Türk Turizm Araştırmaları Dergisi. 


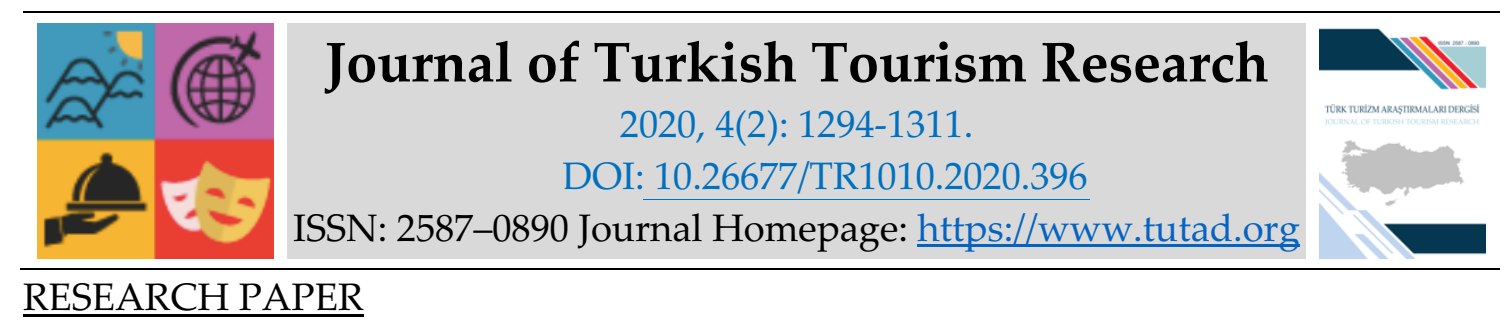

\title{
The Effect of Percieved Atmosphere on Customer Satisfaction in Accommodation Enterprises: The Case of Kuşadası
}

Research Assistant H. Erhan ALTUN, Aydın Adnan Menderes University, Faculty of Tourism, Aydın, e-mail: erhan.altun@adu.edu.tr

ORCID: https://orcid.org/0000-0002-9704-5293

Assistant Prof. Dr. Tuğrul AYYILDIZ, Aydın Adnan Menderes University, Faculty of Tourism, Aydın, e-mail: tayyildiz@adu.edu.tr

ORCID: https://orcid.org/0000-0001-6332-975X

\begin{abstract}
The aim of this study is to investigate the effects of the atmosphere elements in the accommodation establishments on the satisfaction levels of the customers who are purchased services from these establishments. In the study, a quantitative research approach was adopted and the data which were aquired from accommodation establishments with questionnaire forms face to face were analyzed by correlation, regression and nonparametric statistical tests. As a result of the analyzes, $34.4 \%$ positive correlation was found between perceived atmosphere and customer satisfaction. It's been found that each of the perceived atmosphere dimensions affects at least three of the customer satisfaction dimensions. It has been observed that the internal variables dimension of perceived atmosphere has the highest effect on the tangibles dimension of customer satisfaction with $40.9 \%$. The lowest impact $(12.8 \%)$ is between the employee and hygiene variables dimension of the perceived atmosphere and the assurance dimension of customer satisfaction. In atmosphere perceptions, it has been concluded that the average of the rows of regular customers is higher than the new customers. On the other hand, it was found that customer satisfaction was not affected by demographic variables.
\end{abstract}

Keywords: Atmosphere, Kuşadası, Customer Satisfaction.

Received: 24.12 .2019

Accepted: 03.04.2020

Suggested Citation:

Altun, H. E. and Ayyıldız, T. (2020). The Effect of Percieved Atmosphere on Customer Satisfaction in Accommodation Enterprises: The Case of Kuşadası, Journal of Turkish Tourism Research, 4(2): 1294-1311.

(C) 2020 Türk Turizm Araştırmaları Dergisi. 


\section{Gíriş}

Hizmetlerin soyut olma özelliği, bunları satın alan tüketiciler tarafından değerlendirilmelerini güçleştirmektedir. Bu husus, hizmet işletmelerinin tüketicilere sundukları hizmeti somut unsurlarla desteklemeleri zorunluluğunu doğurmaktadır. Örneğin konaklama işletmeleri, konuklarına sundukları konforu broşürlerle resmederek somutlaştırmaktadır (Rızaoğlu, 2007: 34-35).

Hizmet işletmelerindeki fiziksel kanıtların varlı̆̆ı, tüketim öncesi, esnası ve sonrasında tüketicilerin kendi tatmin düzeylerine ilişkin değer biçmelerini kolaylaştırmaktadır (Zeithaml vd., 2013: 278). Bu nedenle hizmet işletmelerinde tüketicilerin etkileşim kuracağı alanları tasarlayanlar; iklendirme, üniformalar veya ortam kokusu gibi pek çok değişken üzerinde çalışarak arzu ettikleri tüketici (ve hatta işgören) davranışlarını ve duygu durumlarını tetiklemeye çalışmakta (Babin vd., 2003: 541), ayrıca sunulan hizmeti farklılaştırarak rekabet avantajında öne geçmeye gayret göstermektedirler (Hoegg ve Alba, 2008:733).

İşletmelerin genel fiziksel çevresi, atmosfer terimiyle kavramlaştırılarak (Bruhn ve Georgi, 2006: 321) bu araştırmanın değişkenlerinden bir tanesini oluşturmaktadır. Kuramsal çerçeve bölümünde ilk olarak açıklanacak olan atmosfer kavramı Kotler ve arkadaşlarının (2014: 255) işaret ettiği şekilde hizmetlerde kritik bir unsur olmakta, dahası, satın alma davranışının tek nedeni dahi olabilmektedir. Araştırmanın bağımsız değişkeni ise işletmelerin bekası açısından uzun yıllardır pek çok araştırmanın konusunu teşkil etmiş olan müşteri tatminidir ve atmosfer kavramı ardınan ele alınmaktadır. Uygulama kısmında ise Kuşadası'nda konaklayan turistlerden elde edilen verilerin analizinden elde edilen bulgular paylaşılmaktadır.

\section{KURAMSAL ÇERÇEVE}

\section{Atmosfer}

Atmosfer, gerek günlük yaşamda gerekse de ticari hayatta sıkça telaffuz edilen bir sözcük olmasına rağmen çoğunlukla farklı anlamlarda kullanılan muğlak bir kavramdır. Günlük hayatta mecaz anlamıla "içinde yaşanılan ve etkisinde kalınan ortam, hava" (TDK, 2017) olarak kullandığımız kavramın pazarlama literatüründe ele alınışına ilişkin ilk kapsamlı araştırma için genellikle Kotler'e atıfta bulunulmuştur (örneğin Countryman, 2001:10; Karkın, 2008:23; Kılıçarslan, 2016:1). Kotler (1973:50), müşteriler üzerinde bilinçli etkiler oluşturmak için çevresel değişkenlerin tasarlanmasını atmosferik terimiyle izah etmiş, kavramın boyutlarını görsel, işitsel, kokusal ve dokunsal boyutlar olmak üzere dört başlık altında ele almıştır. Öte yandan Turley ve Milliman (2000:193), atmosfer çalışmalarının 1960'lı yıllarda başladığını belirtmişler, Birtwistle (2001: 39) ise 1958 yılında Martineu tarafından yayınlanan "mağaza kişiliği" ile ilgili yazıyı atmosfer çalışmalarının başlangıcı olarak göstermişlerdir. Altmışlı yıllar incelendiğinde Feder' in (1965: 66) ve Motto'nun (1965: 75) atmosferle ilgili tanımlarına rastlamak mümkündür. Baker (1986:79) hizmet alanında sunulan fiziki olanakları "fiziksel çevre" söz öbeğiyle kavramlaştırarak, ambiyans etmenleri, tasarım etmenleri ve sosyal etmenler olarak üç boyutta ele almıştır. Bitner (1992: 65), "hizmet uzantısı" (veya hizmet çerçevesi, hizmet çatısı) kavramını ambiyans koşulları, mekan düzen ve işlevi, ve son olarak da işaretler, semboller ve yapay dokular olarak yine üç boyutta incelemiştir. Turley ve Milliman (2000: 193-194), "pazarlama çevresi" kavramıla ele aldıkları fiziki koşulları beş boyutta çalışmışlardır: dışsal değişkenler, genel içsel değişkenler, düzen ve tasarım değişkenleri, satın alma noktası ve dekorasyon değişkenleri, beşeri değişkenler. Lin'e (2004: 167-170) göre kavramın boyutlarını görsel, işitsel ve kokusal ipuçları olarak üçe ayırmak mümkündür. 
Atmosferi bir mağazada tüketicilerin zihinlerinde imaj oluşturan, mimari, yerleşim düzeni, işaret ve görüntüler, renk, aydınlatma, 1sı, ses ve kokulardaki fiziksel nitelikler (AMA, 2017) olarak tanımlamak mümkündür. Konaklama işletmeleri özelinde bir atmosfer tanımını Aksu (2012: 42), işletmenin iç ve dış görünümü, düzenlenmesi ve çalışanları gibi müşterilerin o konaklama işletmesi hakkında algılarını etkileyen fiziksel unsurlarının bütünü olarak ifade etmiştir.

Atmosfer, işletmede bulunan tüketici ve işgörenleri olumlu veya olumsuz yönde etkileme potansiyeline sahiptir. Bu etkileri Kotler ve arkadaşları (2014: 255-256) dört boyutta ele almışlardır: atmosferin ilgi oluşturan bir ortam sağlaması, ileti oluşturan bir ortam sağlaması, etki oluşturan bir ortam sağlaması ve ruh halini farklılaştıran bir ortam sağlaması. Bununla beraber, atmosfer etkilerinin gözardı edilebildiği işletmeler de mevcuttur (Varinli, 2005: 182-183). Örneğin bir un fabrikasındaki atmosfer unsurlarının etkilerinin kısıtlı olduğu ve bu kısıtlı etkilerin sadece işgörenleri etkileyeceği düşünülebilir.

\section{Müşteri Tatmini}

Örgütlerin uzun dönem beka ve başarılarının belirleyicilerinden biri olan müşteri tatmini konusu gerek pazarlama gerekse de yönetim alanlarında etraflıca ele alınmış, bununla beraber üzerinde karar birliğine varılmış ortak bir tanım geliştirilememiştir (Dörtyol, 2014:154). Oliver (1999:34), müşteri tatminini tüketim deneyimi üzerindeki bütünsel değerlendirmeler olarak ifade etmiştir. Müşterinin satın alma öncesinde mal ve hizmetlerden bir takım beklentileri bulunmakta, satın alma sonrası mal ve hizmetlerin başarımına yönelik yapılan değerlendirmeler beklentilerle karşılaştırılmakta ve tatmin olma veya olmama durumu ortaya çıkmaktadır (Iacobucci vd., 1994:93). Bu durum Beklenti-Onaylamama Modeli ile gösterilmiştir. Modele göre onaylama duygusu tüketilen mal veya hizmetin performansı ile o mal veya hizmetten tüketim öncesi beklentiler arasındaki farkın bir fonksiyonudur. Satın alınan mal veya hizmetin algi-beklenti kıyaslaması üç duygu ortaya çıkarmaktadır. Algılanan performansın beklentiden yüksek olması onaylamayı, zıttı durumda ise onaylamama ortaya çıkarmaktadır. Algılanan performansın beklentiye eşit olduğu noktada ne onaylama ne de onaylamama söz konusudur (Caruna vd., 2000:1341).

Beklenti ve algılama arasındaki farka yoğunlanan bir başka kuram ise Boşluklar Modeli'dir. Parasuraman ve arkadaşları (1985) beş farklı katmanda oluşan boşlukların algı-beklenti farkını doğurduğunu savunmuşlardır. Bu katmanlar; (i) müşteri beklentileri ile örgüt yöneticisinin bu beklentilere ilişkin düşünceleri arasındaki fark, (ii) örgüt yöneticisinin müşteri beklentilerine ilişkin düşünceleri ile sunulan hizmetteki kalite nitelikleri arasındaki fark, (iii) hizmet kalitesi nitelikleri ile sunulan hizmetin kendisi arasındaki fark, (iv) hizmet seviyesi ile hizmete ilişkin iletilmiş mesajlar arasındaki fark ve (v) müşterilerin tüketilecek hizmete yönelik beklentileriyle o hizmetin performansına ilişkin algılamaları arasındaki fark olarak belirlenmiştir.

\section{YÖNTEM}

\section{Araştırma Modeli}

Araştırmada konaklama işletmesi müşterilerinin algıladıkları atmosfer unsurlarının müşteri tatmin düzeylerini ne ölçüde etkilediği bulunmaya çalışılmıştır. Bunun için nicel bir metod benimsenerek, betimsel verileri ortaya koyarak istatistiksel analizlerin tatbikini mümkün kılan tarama modeli (Karasar, 2005:183) benimsenmiştir. 


\section{Evren ve Örneklem}

Araştırma evreni Türkiye'de turizm hareketlerine dahil olarak konaklama hizmeti tüketen yerli ve yabancı turistlerden oluşmaktadır. Gerek zaman, gerekse de parasal kısıtların mevcudiyeti ve Kuşadası ilçesinin Türkiye'de turizmin öncü destinasyonlarından biri olmasından dolayı sahip olduğu konaklama işletmesi ve turist zenginliğiyle araştırma evrenini makul ölçüde temsil edeceği düşünülmüştür. Bu nedenle araştırma, Kuşadası'nda hizmet veren konaklama tesislerinden 5 yıldızlı otel ve 5 yıldızlı tatil köyleri ile üst düzey hizmet sunan butik otel müşterileri üzerinde yürütülmüsstür. Araştırmanın yapıldığı sonbahar aylarında bazı işletmelerin kapalı olması neticesinde 6 adet 5 yıldızlı otel ve 1 butik otel müşterileri örneklem çerçevesini oluşturmuştur.

Kolayda (uygun) örnekleme yöntemi benimsenerek yüz yüze uygulanan anket formları ile \%95 güven aralığı, \%5 hata payı ile 384 katılımcıdan veri toplamak amaçlanmıştır. Bu doğrultuda işletmede gönüllü olan işgörenlere 2200 form dağıtılmış, 497 form geri dönmüş ve 386 adeti sağlıklı veri bütünlüğü gösterdiği kararıyla analizlere dahil edilmiştir. Örneklem profiline ait veriler Tablo 1'de yer almaktadır.

Tablo 1. Örneklem Profili

\begin{tabular}{|c|c|c|c|c|c|}
\hline Değişken & $\mathrm{n}$ & $\%$ & Değişken & $\mathbf{n}$ & $\%$ \\
\hline \multicolumn{3}{|l|}{ Cinsiyet } & \multicolumn{3}{|l|}{ Milliyet } \\
\hline Erkek & 213 & 55.2 & Türk & 322 & 83.4 \\
\hline Kadın & 173 & 44.8 & Yabanc1 & 64 & 16.6 \\
\hline Toplam & 386 & 100 & Toplam & 386 & 100 \\
\hline \multicolumn{3}{|l|}{ Medeni Durum } & \multicolumn{3}{|c|}{ Çocuk sayısı } \\
\hline Bekar & 165 & 42.7 & Yok & 209 & 54.1 \\
\hline Evli & 186 & 48.2 & $1-3$ & 154 & 39.9 \\
\hline Boşanmış veya dul & 35 & 9.1 & 4 ve üzeri & 23 & 6.0 \\
\hline Toplam & 386 & 100 & Toplam & 386 & 100 \\
\hline \multicolumn{3}{|l|}{ Yaş } & \multicolumn{3}{|c|}{ Eğitim durumu } \\
\hline 19 ve altı & 24 & 6.2 & İlköğretim & 30 & 7.8 \\
\hline $20-29$ & 140 & 36.3 & Lise & 121 & 31.3 \\
\hline $30-39$ & 110 & 28.5 & Ön lisans & 76 & 19.7 \\
\hline $40-49$ & 71 & 18.4 & Lisans & 123 & 31.9 \\
\hline $50-59$ & 31 & 8.0 & Lisans üstü & 36 & 9.3 \\
\hline 60 ve üzeri & 10 & 2.6 & Toplam & 386 & 100 \\
\hline Toplam & 386 & 100 & \multicolumn{3}{|c|}{ Aynı otelde daha önce konaklama durumu } \\
\hline \multicolumn{3}{|c|}{ Otelde konaklama sıklığı } & Evet & 140 & 36.3 \\
\hline Birkaç yılda bir kez & 90 & 23.3 & Hayır & 246 & 63.7 \\
\hline Yllda bir kez & 164 & 42.5 & Toplam & 386 & 100 \\
\hline Yilda birkaç kez & 132 & 34.2 & \multicolumn{3}{|l|}{ Otel türü } \\
\hline \multirow[t]{3}{*}{ Toplam } & 386 & 100 & 5 yıldız & 329 & 85.2 \\
\hline & & & Butik & 57 & 14.8 \\
\hline & & & Toplam & 386 & 100 \\
\hline
\end{tabular}

Katılımclara milliyetleri ile ilgili bir soru sorulmamış, İngilizce ve Türkçe olmak üzere iki dilde basılan formlardan İngilizce olanı dolduranlar yabancı, Türkçe formu dolduranlar ise yerli olarak 
kodlanmıştır. Demografik profil incelendiğinde katılımcıların çoğunlukla yerli oldukları ve 5 yıldızlı bir tesiste konakladıkları görülmektedir.

\section{Veri Toplama Araçları}

Veri toplamada kullanılan anket formlarında katılımcılara 3 bölümde 103 soru sorulmuştur. Formun ilk bölümde hizmet kalitesi ölçümü için geliştirilen ve müşteri tatmini ölçüm aracı olarak da (örneğin Keser, 2007; Aslan vd., 2008; Zaim ve Tarım, 2010; Al-Neyadi vd., 2018) kullanılan SERVQUAL ölçeği yer almıştır. Parasuraman ve arkadaşlarının (1985) geliştirdiği ölçekte hizmet tüketme öncesinde beklentilerin ölçüldügü 22 ifade ve hizmet tüketme sonrasında deneyimlerin ölçüldüğü 22 ifade 5 boyutta yer almaktadır. Beşli Likert formatında konaklama işletmelerine uygun bir dille düzenlenen ölçekte müşterilerin satın alacakları hizmete ilişkin beklenti skorları satın aldıkları hizmetten algıladıkları performans skorlarından çıkartılarak tatmin düzeyleri belirlenmektedir. Buna göre beklenti skorlarının algılama skorlarına eşit olduğu noktada müşteri tatmini sağlandığı ifade edilmektedir.

İkinci bölümde 51 ifadeden oluşan atmosfer ölçeği yer almıştır. Turley ve Milliman (2000) tarafından mağazalar için geliştirilen ve konaklama işletmeleri için Aksu (2014) tarafından uyarlanan ölçek kapsam genişliği nedeniyle kullanışlı bulunmuştur. Beş boyuttan oluşan ölçek, 5’li Likert formatında düzenlenmiştir.

Anket formunun üçüncü bölümünde ise demografik ifadeler (yaş, cinsiyet, meslek, medeni durum, eğitim, çocuk sahibi olma, konaklama satın alma sıklığı, devamlı müşteri olma) yer almaktadır. Katılımcılara ayrıca meslekleri açık uçlu soruyla sorulmuş, fakat yanıtlar yeterli ağırlıklarda kümelenmediği değerlendirmesiyle analizlere dahil edilmemiştir. Anket formlarının çevirisi, Aydın Adnan Menderes Üniversitesi Turizm Fakültesi öğretim elemanlarından uzman görüşü alınarak son haline getirilmiştir. Hazırlanan formlar butik bir otel işletmesinde 57 kişilik örnek kütle üzerinde ön teste tabi tutulmuş ve herhangi bir değişikliğe gerek olmadığına kanaat getirilerek uygulama için dağıtılmıştır.

\section{Verilerin Analizi}

Gerek SERVQUAL ölçeğinin beklenti ve algılama bölümlerinden, gerekse de atmosfer ölçeğinden elde edilen veriler Kolmogorov-Simirnov ve Shapiro-Wilk testlerine tabi tutulmuş, anlamlılık değeri .000 olarak görülmüştür. Öte yandan basıklık ve çarpıklığa ilişkin değerler standart hataya bölünerek $z$ değerleri bulunmuş, fakat bu değerlerin kabul sınırları olan -1,96 ile 1,96 aralığ (Field, 2009:26) dışına düşmesi sonucunda parametrik olmayan testler kullanılmıştır. Ölçeklere ilişkin güvenirlik analizleri sonuçları Tablo 2' deki gibidir.

Tablo 2. Güvenirlik Analizi Sonuçları

\begin{tabular}{|l|c|c|}
\hline Ölçek & Cronbach's $\boldsymbol{\alpha}$ & İfade sayısı \\
\hline SERVQUAL Beklentiler & .856 & 22 \\
\hline SERVQUAL Algılamalar & .844 & 22 \\
\hline SERVQUAL Beklentiler+Algılamalar & .919 & 44 \\
\hline Atmosfer & .972 & 51 \\
\hline
\end{tabular}


Alfa değerleri $(\alpha>.80)$ yüksek derecede güvenilir (Kalaycı, 2014:405) görülen ölçeklerde silinmesi durumunda değeri .001 ve .002 artıracak birer ifade görülmüş, fakat Field'in (2009:679) savunduğu şekilde güvenirlik düzeyleri halihazırda yüksek olan ölçeklerin bütünlüğünü korumak adına bu ifadeler silinmemiştir.

\section{BULGULAR}

Takip eden başlıklarda SERVQUAL skorlarına ilişkin bulgular, ölçeklere ilişkin faktör analizleri, demografik özelliklerin müşteri tatmini ve atmosfer algılamalarına olan etkileri ve regresyon analizi sonuçları paylaşılmaktadır.

\section{SERVQUAL Skorlarına İlişkin Bulgular}

SERVQUAL ölçeğinin beklentiler ve algılamalar bölümlerine ait betimleyici istatistikler ile SERVQUAL boyutlarına yönelik skorlar Tablo 3'te yer almaktadır.

Tablo 3. SERVQUAL Betimleyici İstatistikleri ve Skorları

\begin{tabular}{|c|c|c|c|c|c|c|c|c|}
\hline \multirow[b]{2}{*}{ Boyut } & \multirow[b]{2}{*}{ İfade } & \multicolumn{2}{|c|}{ Beklentiler } & \multicolumn{2}{|c|}{ Algılamalar } & \multirow[b]{2}{*}{$\begin{array}{l}\text { Boşluk } \\
\text { Skoru* }\end{array}$} & \multirow[b]{2}{*}{$\begin{array}{c}\text { Boyut } \\
\text { Skoru }^{* *}\end{array}$} & \multirow[b]{2}{*}{$\begin{array}{c}\text { SERVQUAL } \\
\text { Skoru }^{* * * *}\end{array}$} \\
\hline & & $\begin{array}{l}\text { Orta- } \\
\text { lama }\end{array}$ & $\begin{array}{r}\text { St. } \\
\text { Sapma }\end{array}$ & $\begin{array}{l}\text { Orta- } \\
\text { lama }\end{array}$ & $\begin{array}{r}\text { St. } \\
\text { Sapma }\end{array}$ & & & \\
\hline \multirow{4}{*}{ 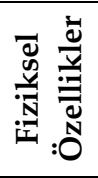 } & $\mathrm{F} 1$ & 4.5026 & .89805 & 3.8238 & 1.16888 & -.6788 & \multirow{4}{*}{-.5886} & \multirow{22}{*}{-.2015} \\
\hline & F2 & 4.3912 & .87673 & 3.8203 & 1.07462 & -.5709 & & \\
\hline & F3 & 4.4802 & .89385 & 3.8717 & 1.12436 & -.6085 & & \\
\hline & $\mathrm{F} 4$ & 4.4144 & .85960 & 3.9181 & 1.06717 & -.4963 & & \\
\hline \multirow{5}{*}{ 范 } & G1 & 4.4701 & .86175 & 3.8747 & 1.11889 & -.5954 & \multirow{5}{*}{-.4464} & \\
\hline & G2 & 4.4530 & .88444 & 3.9585 & 1.06336 & -.4945 & & \\
\hline & G3 & 4.4087 & .90426 & 4.0077 & 1.00773 & -.4010 & & \\
\hline & G4 & 4.4039 & .86453 & 3.9294 & 1.04830 & -.4745 & & \\
\hline & G5 & 4.3693 & .98949 & 4.1026 & .96025 & -.2667 & & \\
\hline \multirow{4}{*}{ 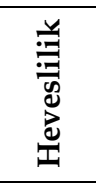 } & H1 & 3.0181 & 1.47258 & 3.2521 & 1.37477 & .2340 & \multirow{4}{*}{.1302} & \\
\hline & $\mathrm{H} 2$ & 3.1481 & 1.40836 & 3.2270 & 1.34011 & .0789 & & \\
\hline & $\mathrm{H} 3$ & 3.4118 & 1.43280 & 3.5975 & 1.37758 & .1857 & & \\
\hline & $\mathrm{H} 4$ & 3.4341 & 1.40262 & 3.4564 & 1.34882 & .0223 & & \\
\hline \multirow{4}{*}{ 苛 } & GV1 & 4.2245 & 1.03784 & 4.0026 & 1.00776 & -.2219 & \multirow{4}{*}{-.3420} & \\
\hline & GV2 & 4.3543 & .94868 & 4.0681 & .96191 & -.2862 & & \\
\hline & GV3 & 4.4092 & .89792 & 4.0833 & .96070 & -.3259 & & \\
\hline & GV4 & 4.3395 & .97396 & 3.8053 & 1.20990 & -.5342 & & \\
\hline \multirow{5}{*}{ 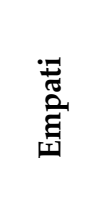 } & E1 & 2.5168 & 1.24278 & 2.8288 & 1.25444 & .3120 & \multirow{5}{*}{.2395} & \\
\hline & E2 & 2.5413 & 1.24132 & 2.8389 & 1.28035 & .2976 & & \\
\hline & E3 & 2.6436 & 1.22454 & 2.8863 & 1.31231 & .2427 & & \\
\hline & E4 & 2.7758 & 1.27891 & 2.9845 & 1.33476 & .2087 & & \\
\hline & E5 & 2.8557 & 1.32705 & 2.9923 & 1.31028 & .1366 & & \\
\hline
\end{tabular}

$\mathrm{N}=386$; min=1, maks=5; *Boşluk skoru: Alg1lamalar ortalaması-Beklentiler ortalaması; ${ }^{* *}$ Boyut

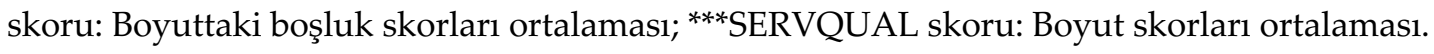




\section{SERVQUAL Ölçeği Faktör Analizi}

SERVQUAL sonuçlarından elde edilen ifade skorları üzerinde faktör analizi uygulanmıştır. Uygulanan analizde Varimax rotasyonu kullanılmıştır. Analiz sonucunda KMO değeri .786 ve Bartlett testi anlamlılık değeri .000 olarak karşımıza çıkmıştır. Buradan hareketle verilerin faktör analizine uygun olduğu belirlenmiştir. Analiz esnasında ortak varyans değeri düşük olan veya aynı faktörde birbirine yakın yük alan ifadeler işlemden çıkarılmıştır. Toplam varyansı \%58.955 oranında açıklayan faktör yapısına ilişkin matris ve boyutların alfa değerleri Tablo 4'te yer almaktadır

Tablo 4. SERVQUAL Ölçeği Faktör Analizi

\begin{tabular}{|c|c|c|c|c|}
\hline Boyut ve ifade & Faktör yükleri & Özdeğer & Açıklanan varyans (\%) & Cronbach's $\alpha$ \\
\hline Fiziksel Özellikler & & 2.769 & 13.847 & .823 \\
\hline F1 & .817 & & & \\
\hline F2 & .798 & & & \\
\hline F3 & .749 & & & \\
\hline $\mathrm{F} 4$ & .622 & & & \\
\hline Güvenilirlik & & 4.464 & 22.322 & .777 \\
\hline G1 & .621 & & & \\
\hline G2 & .739 & & & \\
\hline G3 & .641 & & & \\
\hline G4 & .705 & & & \\
\hline G5 & .686 & & & \\
\hline Heveslilik & & 1.626 & 8.130 & .646 \\
\hline $\mathrm{H} 1$ & .661 & & & \\
\hline $\mathrm{H} 2$ & .656 & & & \\
\hline $\mathrm{H} 3$ & .719 & & & \\
\hline $\mathrm{H} 4$ & .719 & & & \\
\hline Güven & & 1.195 & 5.973 & .680 \\
\hline GV1 & .782 & & & \\
\hline GV2 & .785 & & & \\
\hline GV3 & .689 & & & \\
\hline Empati & & 1.736 & 8.682 & .799 \\
\hline E1 & .807 & & & \\
\hline E2 & .797 & & & \\
\hline E3 & .791 & & & \\
\hline E4 & .746 & & & \\
\hline
\end{tabular}

Tabloda görülen yapı, SERVQUAL ölçeğindeki özgün yapıyla büyük benzerlikler göstermektedir. 22 ifade içerisinden 2 tanesi (E5 ve GV4) elenmiş, bununla beraber orjinal ölçekteki boyutları oluşturan ifadelerin yerleri değişmemiştir. 


\section{Atmosfer Ölçeği Faktör Analizi}

Aksu'nun (2012) uyarlamış olduğu atmosfer ölçeği değişkenleri üzerinde faktör analizi uygulanmıştır. Uygulanan analizde Varimax rotasyonu kullanılmıştır. Analiz sonucunda KMO değeri .955 ve Bartlett testi anlamlılık değeri .000 olarak karşımıza çıkmıştır.

Tablo 5. Atmosfer Ölçeği Faktör Analizi

\begin{tabular}{|c|c|c|c|c|}
\hline Boyut ve ifade & Faktör yükleri & Özdeğer & Açıklanan varyans (\%) & Cronbach's $\alpha$ \\
\hline $\begin{array}{l}\text { Genel içsel ve dişsal } \\
\text { değişkenler }\end{array}$ & & 13.3222 & 47.580 & .925 \\
\hline ATM9 & .769 & & & \\
\hline ATM8 & .760 & & & \\
\hline ATM7 & .758 & & & \\
\hline ATM18 & .727 & & & \\
\hline ATM22 & .709 & & & \\
\hline ATM19 & .685 & & & \\
\hline ATM23 & .676 & & & \\
\hline ATM21 & .626 & & & \\
\hline $\begin{array}{l}\text { Düzen ve tasarım } \\
\text { değişkenleri }\end{array}$ & & 2.183 & 7.795 & .910 \\
\hline ATM28 & .720 & & & \\
\hline ATM27 & .710 & & & \\
\hline ATM29 & .703 & & & \\
\hline ATM26 & .698 & & & \\
\hline ATM30 & .669 & & & \\
\hline ATM25 & .631 & & & \\
\hline ATM24 & .627 & & & \\
\hline ATM31 & .615 & & & \\
\hline $\begin{array}{l}\text { Çalışanlarla ve hijyenle } \\
\text { ilgili değişkenler }\end{array}$ & & 1.652 & 5.901 & .901 \\
\hline ATM42 & .785 & & & \\
\hline ATM44 & .770 & & & \\
\hline ATM43 & .751 & & & \\
\hline ATM45 & .704 & & & \\
\hline ATM41 & .593 & & & \\
\hline ATM50 & .592 & & & \\
\hline ATM47 & .582 & & & \\
\hline ATM13 & .533 & & & \\
\hline Kayıt yeri değişkenleri & & 1.087 & 3.881 & .873 \\
\hline ATM36 & .755 & & & \\
\hline ATM35 & .708 & & & \\
\hline ATM37 & .656 & & & \\
\hline ATM34 & .610 & & & \\
\hline
\end{tabular}


Buradan hareketle verilerin faktör analizine uygun olduğu belirlenmiştir.Analiz esnasında gerek ortak varyans değeri düşük olan, gerekse de farklı faktörler içerisinde benzer yüklere sahip olan $(1,2,3,4,5,6,10,11,12,14,15,16,17,20,32,33,38,39,40,46,48,49$ ve 51.) ifadeler çıkartılmıştır. Açıklanan toplam varyans \%65.157 olarak karşımıza çıkmıştır. Elde edilen faktör matrisi ve boyutların alfa değerleri Tablo 5'te yer almaktadır.

Tabloda görülen yapının kaynak ölçekteki yapı ilebüyükölçüde farklılaşttğııı ifade etmek mümkündür. Toplam 51 madde arasından 23'ü elenerek, 4 boyutta toplam 28 madde kümeleşmiştir. Yeni boyutlar ise genel içsel ve dışsal değişkenler, düzen ve tasarım değişkenleri, çalışanlarla ve hijyenle ilgili değişkenler ve kayıt yeri değişkenleri olarak isimlendirilmiştir.

\section{Demografik Özelliklere Göre Müşteri Tatmini ve Algılanan Atmosfer}

Katılımcların demografik özelliklerine göre tatmin düzeyleri ve algılanan atmosfer arasında bir fark olup olmadığ irdelenmek üzere aşağıdaki yokluk hipotezleri kurulmuştur.

- H0a: Katılımciların cinsiyetine göre tatmin düzeyleri arasında fark yoktur.

- H0b: Katılımcıların aynı otelde daha önce konaklama durumlarına göre tatmin düzeyleri arasinda fark yoktur.

- H0c: Katılımcıların yaşlarına göre tatmin düzeyleri arasında fark yoktur.

- H0d: Katılımciların eğitim durumlarına göre tatmin düzeyleri arasında fark yoktur.

- H0e: Katılımciların medeni durumlarına göre tatmin düzeyleri arasında fark yoktur.

- H0f: Katılımcıların çocuk sayılarına göre tatmin düzeyleri arasında fark yoktur.

- H0: Katılımciların konaklama sıklıklarına göre tatmin düzeyleri arasında fark yoktur.

- H0h: Katılımciların cinsiyetine göre algilanan atmosfer düzeyleri arasında fark yoktur.

- H0: Katılımcıların aynı otelde daha önce konaklama durumlarına göre algılanan atmosfer düzeyleri arasında fark yoktur.

- H0;: Katılımciların yaşlarına göre algilanan atmosfer düzeyleri arasında fark yoktur.

- H0k: Katılımcıların eğitim durumlarına göre algılanan atmosfer düzeyleri arasında fark yoktur.

- H0ı: Katılımclıların medeni durumlarına göre algılanan atmosfer düzeyleri arasında fark yoktur.

- H0m: Katılımcıların çocuk sayılarına göre algılanan atmosfer düzeyleri arasında fark yoktur.

- HOn: Katılımcıların konaklama sıklıklarına göre algılanan atmosfer düzeyleri arasında fark yoktur.

Cinsiyet, yaş, eğitim durumu, medeni durum, çocuk sayısı, konaklama sıklı̆̆ı ve aynı oteldeki daha önce konaklayıp konaklamama değişkenlerinin müşteri tatmini üzerindeki etkisi MannWhitney U ve Kruskal Wallis testleriyle sınanmış, sonuçlar Tablo 6'da sunulmuştur.

Yapılan analizler sonucunda herhangi bir demografik özelliğin müşteri tatmini üzerinde etkisi görülmemiştir. Aynı testler algılanan atmosfer üzerinde test edilmiş ve sonuçlar Tablo $7^{\prime}$ de sunulmuştur. 
Tablo 6. Demografik Özelliklere Göre Müşteri Tatmini

\begin{tabular}{|c|c|c|c|c|c|c|}
\hline Cinsiyet & $\mathbf{n}$ & $\begin{array}{c}\text { Siralar } \\
\text { Ortalamasi }\end{array}$ & $\begin{array}{c}\text { Siralar } \\
\text { Toplamı }\end{array}$ & $\begin{array}{c}p \\
\text { (iki uçlu) }\end{array}$ & Test & Ho \\
\hline Kadın & 173 & 193.48 & 33472.00 & \multirow{2}{*}{.997} & \multirow{2}{*}{$\begin{array}{c}\text { Mann- } \\
\text { Whitney U }\end{array}$} & \multirow{2}{*}{ Kabu } \\
\hline Erkek & 213 & 193.52 & 41219.00 & & & \\
\hline \multicolumn{7}{|l|}{ Önceki Konaklama } \\
\hline Evet & 140 & 204.23 & 28591.50 & \multirow{2}{*}{.154} & \multirow{2}{*}{$\begin{array}{c}\text { Mann- } \\
\text { Whitney U }\end{array}$} & \multirow{2}{*}{ Kabul } \\
\hline Hayır & 246 & 187.40 & 46099.50 & & & \\
\hline Yaş & & & & p & & \\
\hline 19 ve altı & 24 & 234.13 & & \multirow{6}{*}{.058} & \multirow{6}{*}{$\begin{array}{l}\text { Kruskal } \\
\text { Wallis }\end{array}$} & \multirow{6}{*}{ Kabul } \\
\hline $20-29$ & 140 & 203.01 & & & & \\
\hline $30-39$ & 110 & 169.15 & & & & \\
\hline $40-49$ & 71 & 188.37 & & & & \\
\hline $50-59$ & 31 & 210.26 & & & & \\
\hline 60 ve üzeri & 10 & 215.20 & & & & \\
\hline \multicolumn{7}{|l|}{ Eğitim Durumu } \\
\hline İlköğretim & 30 & 176.23 & & \multirow{5}{*}{.906} & \multirow{5}{*}{$\begin{array}{l}\text { Kruskal } \\
\text { Wallis }\end{array}$} & \multirow{5}{*}{ Kabul } \\
\hline Lise & 121 & 197.21 & & & & \\
\hline Ön lisans & 76 & 189.43 & & & & \\
\hline Lisans & 123 & 195.85 & & & & \\
\hline Lisans üstü & 36 & 196.00 & & & & \\
\hline \multicolumn{7}{|l|}{ Medeni Durum } \\
\hline Bekar & 165 & 196.49 & & \multirow{3}{*}{.884} & \multirow{3}{*}{$\begin{array}{l}\text { Kruskal } \\
\text { Wallis }\end{array}$} & \multirow{3}{*}{ Kabul } \\
\hline Evli & 186 & 191.91 & & & & \\
\hline Boşanmış/dul & 35 & 187.86 & & & & \\
\hline \multicolumn{7}{|l|}{ Çocuk Sayısı } \\
\hline Yok & 209 & 190.86 & & \multirow{3}{*}{.225} & \multirow{3}{*}{$\begin{array}{l}\text { Kruskal } \\
\text { Wallis }\end{array}$} & \multirow{3}{*}{ Kabul } \\
\hline $1-3$ aras 1 & 154 & 191.26 & & & & \\
\hline 4 ve üzeri & 23 & 232.48 & & & & \\
\hline \multicolumn{7}{|l|}{ Konaklama Sıklı̆ıı } \\
\hline Birkaç yılda bir kez & 90 & 196.41 & & \multirow{3}{*}{.961} & \multirow{3}{*}{$\begin{array}{l}\text { Kruskal } \\
\text { Wallis }\end{array}$} & \multirow{3}{*}{ Kabul } \\
\hline Yilda bir kez & 164 & 192.56 & & & & \\
\hline Yılda birkaç kez & 132 & 192.68 & & & & \\
\hline
\end{tabular}

Yapılan analizler sonucunda aynı işletmede daha önce konaklamış olma durumu ve yaş değişkenlerinin algılanan atmosfer üzerinde etkisi görülmüş, diğer değişkenlerin etkisi tespit edilmemiştir. Aynı işletmede daha önce konaklamış olanların ilk defa o işletmede konaklayanlara göre sıralar ortalaması daha yüksektir. Yaş değişkeniyle ilgili olarak ise 40-49 yaş aralığındaki müşterilerin sıralar ortalaması en yüksek, 19 ve altı yaş grubundaki müşterilerin ise en düşüktür.

\section{Algılanan Atmosferin SERVQUAL Boyutlarına Etkisi}

Algılanan atmosferin müşteri tatminine olan etkisini analiz etmek için Spearman korelasyon testi ve regresyon analizi kullanılmıştır. Tablo $8^{\prime}$ de Spearman korelasyon testi sonuçları yer almaktadir. 
Tablo 7. Demografik Özelliklere Göre Algılanan Atmosfer

\begin{tabular}{|c|c|c|c|c|c|c|}
\hline Cinsiyet & $\mathbf{n}$ & $\begin{array}{c}\text { Siralar } \\
\text { Ortalaması }\end{array}$ & $\begin{array}{c}\text { Siralar } \\
\text { Toplamı }\end{array}$ & $\begin{array}{c}\mathrm{p} \\
\text { (iki uçlu) }\end{array}$ & Test & Ho \\
\hline Kadın & 173 & 191.12 & 33064.50 & \multirow{2}{*}{.706} & \multirow{2}{*}{$\begin{array}{c}\text { Mann- } \\
\text { Whitney U }\end{array}$} & \multirow{2}{*}{ Kabu } \\
\hline Erkek & 213 & 195.43 & 41626.50 & & & \\
\hline \multicolumn{7}{|l|}{ Önceki Konaklama } \\
\hline Evet & 140 & 227.63 & 31868.50 & \multirow{2}{*}{.000} & \multirow{2}{*}{$\begin{array}{c}\text { Mann- } \\
\text { Whitney U }\end{array}$} & \multirow{2}{*}{ Ret } \\
\hline Hayır & 246 & 174.08 & 42822.50 & & & \\
\hline Yaş & & & & p & & \\
\hline 19 ve alt1 & 24 & 154.13 & & \multirow{6}{*}{.037} & \multirow{6}{*}{$\begin{array}{l}\text { Kruskal } \\
\text { Wallis }\end{array}$} & \multirow{6}{*}{ Ret } \\
\hline $20-29$ & 140 & 206.23 & & & & \\
\hline $30-39$ & 110 & 173.25 & & & & \\
\hline $40-49$ & 71 & 216.56 & & & & \\
\hline $50-59$ & 31 & 192.53 & & & & \\
\hline 60 ve üzeri & 10 & 171.70 & & & & \\
\hline \multicolumn{7}{|l|}{ Eğitim Durumu } \\
\hline İlköğretim & 30 & 164.02 & & \multirow{5}{*}{.480} & \multirow{5}{*}{$\begin{array}{l}\text { Kruskal } \\
\text { Wallis }\end{array}$} & \multirow{5}{*}{ Kabul } \\
\hline Lise & 121 & 190.76 & & & & \\
\hline Ön lisans & 76 & 189.45 & & & & \\
\hline Lisans & 123 & 202.06 & & & & \\
\hline Lisans üstü & 36 & 206.58 & & & & \\
\hline \multicolumn{7}{|l|}{ Medeni Durum } \\
\hline Bekar & 165 & 195.45 & & \multirow{3}{*}{.923} & \multirow{3}{*}{$\begin{array}{l}\text { Kruskal } \\
\text { Wallis }\end{array}$} & \multirow{3}{*}{ Kabul } \\
\hline Evli & 186 & 192.92 & & & & \\
\hline Boşanmış/dul & 35 & 187.37 & & & & \\
\hline \multicolumn{7}{|l|}{ Çocuk Sayısı } \\
\hline Yok & 209 & 192.19 & & \multirow{3}{*}{.731} & \multirow{3}{*}{$\begin{array}{l}\text { Kruskal } \\
\text { Wallis }\end{array}$} & \multirow{3}{*}{ Kabul } \\
\hline $1-3$ arası & 154 & 192.61 & & & & \\
\hline 4 ve üzeri & 23 & 211.35 & & & & \\
\hline \multicolumn{7}{|l|}{ Konaklama Sıklığı } \\
\hline Birkaç yılda bir kez & 90 & 190.25 & & \multirow{3}{*}{.835} & \multirow{3}{*}{$\begin{array}{l}\text { Kruskal } \\
\text { Wallis }\end{array}$} & \multirow{3}{*}{ Kabul } \\
\hline Y1lda bir kez & 164 & 197.45 & & & & \\
\hline Yilda birkaç kez & 132 & 190.80 & & & & \\
\hline
\end{tabular}

Tablo 8'e göre algılanan atmosfer ve müşteri tatmini arasında \%34.4 oranında ve pozitif yönde bir ilişki söz konusudur. Atmosfer boyutlarıyla SERVQUAL boyutları arasındaki ilişki irdelenecek olduğunda:

i. Genel içsel değişkenler boyutu;fiziksel özellikler boyutu (\%40.9), güvenilirlik boyutu (\%28.1) ve güven boyutu (\%15.3) ile pozitif yönde bir ilişkiye sahiptir.

ii. Düzen ve tasarım değişkenleri boyutu;fiziksel özellikler boyutu (\%33.7), güvenilirlik boyutu (\%33.1) ve güven boyutu (\%21.1) ile pozitif yönde bir ilişkiye sahiptir.

iii. Kayıt yeri değişkenleri boyutu;fiziksel özellikler boyutu (\%32.9), güvenilirlik boyutu (\%30.1) ve güven boyutu (\%19.2) ile pozitif yönde bir ilişkiye sahiptir.

iv. Çalışanlarla ve hijyenle ilgili değişkenler boyutu;güvenilirlik boyutu (\%22.9), fiziksel özellikler boyutu (\%22.6) ve güven boyutu (\%12.8) ile pozitif yönde bir ilişkiye sahiptir.

Model genel olarak değerlendirildiğinde atmosferi oluşturan boyutlar ile müşteri tatmininin empati boyutu ve heveslilik boyutu arasında herhangi bir ilişki tespit edilememiştir. Bununla 
birlikte atmosferi oluşturan boyutların tamamı ile müşteri tatmininin fiziksel özellikler, güvenilirlik ve güven boyutları arasında $\% 12.8$ ile $\% 40.9$ arasında değişen bir ilişki görülmüştür.

Algılanan atmosferin SERVQUAL boyutlarına etkisi Ek 1.'de yer alan regresyon analizi sonuçlarıyla ele alınmıştır. Algılanan atmosfer boyutlarının müşteri tatminine etkisi ile ilgili olarak şu bulgular elde edilmiştir:

i. Genel içsel ve dışsal değişkenler boyutu müşteri tatmininin fiziksel özellikler, güvenilirlik ve güven boyutlarını etkilemektedir. En yüksek açıklama gücü \%22 ile fiziksel özellikler boyutudur. Ardından \%17 ile güven, ve \%10 ile güvenilirlik boyutlarının geldiği görülmüştür.

ii. Düzen ve tasarım değişkenleri boyutu müşteri tatmininin fiziksel özellikler, güvenilirlik ve güven boyutlarını etkilemektedir. En yüksek açılama gücü \%18.6 ile fiziksel özellikler boyutudur. Ardından \%14.4 ile güvenilirlik ve \%2.2 ile güven boyutlarının geldiği görülmüştür.

iii. Kayıt yeri değişkenleri boyutu müşteri tatmininin fiziksel özellikler, güvenilirlik ve güven boyutlarını etkilemektedir. En yüksek açıklama gücü \%13.8 ile fiziksel özellikler boyutudur. Ardından \%12 ile güvenilirlik ve \%3.1 ile güven boyutlarının geldiği görülmüştür.

iv. Çalışanlar ve hijyenle ilgili değişkenleri boyutu müşteri tatmininin fiziksel özellikler, güvenilirlik, heveslilik ve güven boyutlarını etkilemektedir. En yüksek açıklama gücü \%8.1 ile güvenilirlik boyutudur. Ardından \%7.4 ile fiziksel özellikler, \%1.7 ile güven ve \%1.3 ile heveslilik boyutlarının geldiği görülmüştür.

Tablo 8. Spearman Korelasyon Testi

\begin{tabular}{|c|c|c|c|c|c|c|c|}
\hline & & & $\begin{array}{l}\text { Atmosfer } \\
\text { Ortalama } \\
\end{array}$ & $\begin{array}{l}\text { Genel İçsel } \\
\text { Değişkenler }\end{array}$ & $\begin{array}{c}\text { Düzen ve } \\
\text { Tasarım } \\
\text { Değişkenleri }\end{array}$ & $\begin{array}{c}\text { Kayıt Yeri } \\
\text { Değiş- } \\
\text { kenleri }\end{array}$ & $\begin{array}{c}\text { Çalışanlarla } \\
\text { ve Hijyenle } \\
\text { İlgili } \\
\text { Değişkenler }\end{array}$ \\
\hline \multirow{12}{*}{$\begin{array}{l}\text { Spear- } \\
\text { man's } \\
\text { rho }\end{array}$} & \multirow{2}{*}{$\begin{array}{l}\text { SERVQUAL } \\
\text { Ortalama }\end{array}$} & $\begin{array}{l}\text { Korelasyon } \\
\text { Katsay1s1 }\end{array}$ & $.344^{* *}$ & $.314^{* *}$ & $.337^{* *}$ & $.345^{* *}$ & $.262^{* *}$ \\
\hline & & p. $(2$ uçlu $)$ & .000 & .000 & .000 & .000 & .001 \\
\hline & \multirow{2}{*}{$\begin{array}{l}\text { Fiziksel } \\
\text { Özellikler }\end{array}$} & $\begin{array}{l}\text { Korelasyon } \\
\text { Katsayısı }\end{array}$ & $.367^{* *}$ & $.409^{* *}$ & $.337^{* *}$ & $.329^{* *}$ & $.226^{* *}$ \\
\hline & & p. (2 uçlu) & .000 & .000 & .000 & .000 & .000 \\
\hline & \multirow[t]{2}{*}{ Güvenilirlik } & $\begin{array}{l}\text { Korelasyon } \\
\text { Katsay1sı }\end{array}$ & $.315^{* *}$ & $.281^{* *}$ & $.331^{* *}$ & $.301^{* *}$ & $.229^{* *}$ \\
\hline & & p. $(2$ uçlu $)$ & .000 & .000 & .000 & .000 & .000 \\
\hline & \multirow[t]{2}{*}{ Heveslilk } & $\begin{array}{l}\text { Korelasyon } \\
\text { Katsay1sı }\end{array}$ & -.034 & .037 & -.041 & -.056 & -.085 \\
\hline & & p. $(2 \mathrm{uçlu})$ & .551 & .474 & .420 & .275 & .094 \\
\hline & \multirow[t]{2}{*}{ Güven } & $\begin{array}{l}\text { Korelasyon } \\
\text { Katsayıs1 }\end{array}$ & $.207^{* *}$ & $.153^{* *}$ & $.211^{* *}$ & $.192^{* *}$ & $.128^{*}$ \\
\hline & & p. $(2 \mathrm{uçlu})$ & .000 & .003 & .000 & .000 & .012 \\
\hline & \multirow[t]{2}{*}{ Empati } & $\begin{array}{l}\text { Korelasyon } \\
\text { Katsayısı }\end{array}$ & -.030 & -.032 & -.035 & -.044 & -.027 \\
\hline & & p. $(2$ uçlu $)$ & .555 & .526 & .490 & .384 & .601 \\
\hline
\end{tabular}

$\mathrm{N}=386 ;{ }^{*} 0.05$ düzeyinde anlamlı korelasyon $(2 \mathrm{ucclu}) ;{ }^{* *} 0.01$ düzeyinde anlamlı korelasyon $(2$ uçlu). 


\section{SONUÇ VE TARTIŞMA}

Yapılan analizlerde demografik özelliklerin SERVQUAL boyutlarının tamamı ile istatistiksel olarak anlamlı bir farklılık göstermediği bulunmuştur. Karkın (2008) da Sivas ilinde gerçekleştirdiği çalışmasında araştırmamız kapsamında yer verilen demografik değişkenlerle müşteri memnuniyeti arasında bir ilişki görememiştir. SERVQUAL skorlarında müşterilerin konakladıkları işletmelerden genel olarak tatmin olmadıkları görülmektedir. En büyük tatminsizlik ise fiziksel özellikler boyutunda gerçekleşmiştir. Bunun nedeninin, ilçede bulunan tesis envanterinin eski ve bakımsız olmasından kaynaklandığı düşünülmektedir. Kuruluş tarihi çoğunlukla öncelere dayanan tesisler, bir yandan son yıllarda endüstride sahip olan kriz ve güvensizlik iklimiyle, bir yandan da mevcut kurumsal yöneticilik yaklaşımlarının tesiriyle fiziki unsurların yenilenmesi önünde maddi engellere sahip görünmektedir. Kuruluş tarihi günümüze yakın olan tesislerin sunduğu atmosferin ise müşteri beklentilerini karşılama noktasında yetersiz kaldığı değerlendirmesini yapmak mümkündür.

Heveslilik ve empati boyutunda müşteri tatmin noktası yakalanmış, güvenilirlik ve güven boyutlarında ise yakalanamamıştır. İlçede konaklayan turistler, her ne kadar personelin çalışma istekliliğini ve kendilerine kişisel ilgi göstermelerini yeterli bulmuşlarsa da, tesislerin gerek hizmetleri dakik bir şekilde yerine getirme, gerekse de kişisel bilgi ve eşyaları teminat altına alma hususlarında yetersiz kaldıkları kanısındadırlar. Eleren ve Kılıç (2007), Afyonkarahisar ilindeki bir termal otelde yürüttükleri çalışmada 5 SERVQUAL boyutlarında da benzer bir şekilde tatminsizlik tespit etmişlerdir. Tatmin noktasından en uzak boyut yine fiziksel özelliklerdir. Bununla beraber, yazarların çalışmasında devamlı müşteri olma özelliğine göre SERVQUAL sonuçlarını olumlu yönde farklılaştığı tespit edilmiştir. Işın (2012) ise İzmir otellerinde müşteri sadakatini ele alarak bu özelliği etkileyen boyutların önem sırasına göre güvenilirlik, fiziksel özellikler, empati ve güven olduğunu belirlemiştir.

Aksu (2012) ise Bozcada ilçesinde gerçekleştirdiği çalışmasında en yüksek müşteri tatmini sağlayan boyutları sırasıyla güven, güvenilirlik, haveslilik, empati ve fiziksel özellikler olarak belirlemiştir. Bu farklılığın Bozcaada ilçesindeki tesislerin Kuşadası ilçesindekilerden farklı olarak genellikle kırsal turizme odaklanmış, gece hayatından uzak ve küçük ölçekli işletmeler olmasından kaynaklandığı düşünülmektedir. İşletmelerin küçük ölçekli olması, müşterilerle iletişimin daha kişisel uzun vadeli olacağı düşüncesini akılda canlandırmaktadır. Bu varsayım, personelle ilgili tatmin ifadelerinin öne çıkmasını açıklamaktadır. Kuşadası otellerinde ise genellikle kitle turizmi hakimdir.

Müşteri yaşının algılanan atmosferle istatistiksel olarak anlamlı bir farklılık gösterdiği bulunmuştur. Sıra ortalamaları en düşük olan katılımcıların, yaşı en fazla 19 olan bireyler olduğu görülmüştür. En yüksek sıra ortalaması ise $40^{\prime} 1$ yaşlardaki katılımcılarda görülmüştür. Daha yaşlı katılımcılarda ise sıra ortalamaları düşmektedir. Bulgulardan hareketle atmosfer değerlendirmelerinin kabaca orta yaşa yaklaştıkça yükseldiği, görece genç ve yaşlı misafirlerde ise düştügünü ifade etmek mümkündür. Devamlı müşteri olma durumunun ise algılanan atmosfer ile istatistiksel olarak anlamlı bir farklılık gösteren ikinci değişken olduğu karşımıza çıkmıştır. Bulgular, devamlı müşterilerin atmosfer değerlendirmelerinin daha yüksek olduğuna işaret etmektedir. Buradan hareketle müşterilerin atmosfer unsurlarından hoşnut olduğu tesisleri tekrar tercih etme davranışı göstermeleri makul bir açıklama olarak düşünülmektedir. Aksu (2012) da konaklama işletmelerinde sunulan atmosferin müşteri sadakati üzerinde etkisi olduğunu göstermiştir. Bilgiç (2007), Kurt (2008) ve Acar (2009) da mağazalarda yaptıkları araştırmalarda benzer sonuçlar elde etmişlerdir.

Algılanan atmosfer boyutlarından her birinin SERVQUAL boyutlarından en az üç tanesini etkilediği bulunmuştur. Empati boyutu, herhangi bir algılanan atmosfer boyutundan 
etkilenmeyen tek faktör olarak karşımıza çıkmıştır. Empati boyutunda yer alan ifadelerin personel tutum ve davranışlarıyla ilgili olmasından dolayı katılımcıların bu boyutu atmosfer değişkenlerinden başımsız değerlendirmeleri makul görünmektedir. Algılanan atmosfer boyutlarının SERVQUAL boyutlarına etkisini daha detaylı incelendiğinde aşağıdaki değerlendirmeleri yapmak mümkündür:

- Genel içsel ve dişsal değişkenler boyutu: Otelin iç ve dış görünümüyle ilgili ifadelerin kümelendiği boyuttur. Bu boyutta otelin iç ve dış duvarları, renkleri, halıları ve yer döşemeleri, tavanları ve mimarisi gibi fiziksel nitelikler toplanmıştır. Bu boyutun açıklama gücü en yüksek olduğu SERVQUAL boyutu anlaşılır bir şekilde fiziksel özellikler boyutudur.

- Düzen ve tasarım değişkenleri boyutu: Lobinin işlevselliği ve eşya donatımı ile odalardaki düzen ve eşyalar ile ilgili ifadelerin kümelendiği boyuttur. Bu boyut, SERVQUAL boyutlarından en çok fiziksel özellikler ve güvenilirlik boyutlarını açılamaktadır.

- Kayıt yeri değişkenleri boyutu: Kayıt noktasında satın almayla ilgili fiziksel ipuçlarının (bilgilendirici yön okları, klavuzlar ve broşürler, fiyat etiketleri ve promosyonların sunumu gibi) yer aldığı ifadelerin kümelendiği boyuttur. SERVQUAL boyutlarından en çok fiziksel özellikler ve güven boyutlarını açıklama gücüne sahiptir.

- Çalışanlar ve hijyenle ilgili değişkenler boyutu: Genel olarak personel hijyeni ve tutumu ifadelerinin toplandığı boyuttur. En yüksek açılama gücü olduğu SERVQUAL boyutları güvenilirlik ve fiziksel özelliklerdir.

\section{KAYNAKÇA}

Acar, N. (2009). Perakendecilikte Mağaza Atmosferinin Müşteri Sadakatine Etkisi, Yayımlanmamış Doktora Tezi, Erciyes Üniversitesi, Erciyes.

Aksu, M. (2012). Hizmet Kalitesinin Bir Unsuru Olarak Atmosferin Müşteri Sadakatine Etkisi: Bozcaada'daki Otellerde Konaklayan Yerli Turistler Üzerinde Bir Araştırma, Yayımlanmamış Doktora Tezi, Balıkesir Üniversitesi, Balıkesir.

Al-Neyadi, H., Abdallah, S. ve Malik, M. (2018). Measuring Patient's Satisfaction of Healthcare Services in yhe UAE Hospitals: Using SERVQUAL, International Journal of Healthcare Management, 11(2); 96-105

APA. (2017). Dictionary. https://www.ama.org/resources/Pages/Dictionary.aspx> [Erişim Tarihi: 22.10.2017].

Aslan, Ş., Sezgin, M. ve Haşıloğlu, S. B. (2008). Özel Sağlık Kuruluşlarında Müşteri Memnuniyeti ve Memnuniyeti Oluşturan Unsurların Araştırılması, Muğla Üniversitesi Sosyal Bilimler Enstitüsü Dergisi, Bahar 2008(20): 23-40.

Babin, B. J., Hardesty, D. M. and Suter, T. A. (2003). Color and Shopping İntentions: The Intervening Effect of Price Fairness and Perceived Affect, Journal of Business Research, 56(2003): 541-551.

Baker, J. (1986). The role of the Environment in Marketing Services: The Consumer Perspective, (Editör) J. Czepiel, C. Congram, and J. Shanahan: The Services Challenge: Integrating For Competitive Advantage içinde (ss.79-84) Chicago: American Marketing Association.

Bilgiç, H. E. (2007). The Effect of Store Atmosphere on Store Loyalty Intentions of Department Store Customers In Istanbul, Yayınlanmamış Yüksek Lisans Tezi, Marmara Üniversitesi, İstanbul. 
Birtwistle, G. (2001). Customer and Company Perspectives of Store Positioning: A Study of the UK Specialist Menswear Fashion Sector, Yayımlanmamış Doktora Tezi. Stirling Üniversitesi, Stirling.

Bitner, M. J. (1992). Servicescapes: The impact of Physical Surroundings on Customers and Employees, Journal of Marketing, 56(2): 57-71.

Bruhn, M. and Georgi, D. (2006). Service Marketing: Managing the Service Value Chain. Essex: Pearson Education.

Caruna, A., Money, A. H. and Berthon, P. R. (2000). Service Quality Andsatisfaction - The Moderating Role of Value, European Journal of Marketing, 34(11/12):1338-1352.

Countryman, C. C. (2001). An Atmospheric Scale for the Evaluation of Hotel Lobbies, Yayınlanmamış Doktora Tezi, Purdue Üniversitesi, Lafayette.

Dörtyol, İ. T. (2014). Ulusal Kültür Perspektifinden Hizmet Kalitesi ve Müşteri Değeri. İstanbul: Beta Yayıncilik.

Eleren, A., ve Kılıç, B. (2007). Turizm Sektöründe SERVQUAL Analizi ile Hizmet Kalitesinin Ölçülmesi ve Bir Termal Otelde Uygulama, Afyon Kocatepe Üniversitesi İ.I.B.F. Dergisi, 9(1): 235263.

Feder, A. (1965). Atmosphere and Lighting, Cornell Hospitality Quarterly, 6(3):66-68.

Field, A. (2009). Discovering Statistics Using SPSS. (3. Basım). Londra: Sage.

Hoegg, J. and Alba, J. W. (2008). A Role for Aesthetics in Consumer Psychology, (Editör) C. P. Haugtvedt, P. M. Herr and F. R. Kardes.: Handbook of Consumer Psychology içinde (ss.733-754) New York: Pscyhology Press.

Iacobucci, D., Grayson, K., and Ostroom, A. (1994). Customer Satisfaction Fables, Sloan Management Review, Summer(1994):93-96.

Işın, A. (2012). Yerli ve Yabancı Turistlerin Otel İşletmelerinde Sunulan Hizmet Kalitesi Algılamalarının Müşteri Sadakati Üzerine Etkisi, Yayımlanmamış Yüksek Lisans Tezi, Gazi Üniversitesi, Ankara.

Kalaycı, Ş. (2014). Spss Uygulamalı Çok Değgişkenli İstatistik Teknikleri. Ankara: Asil Yayın Dağııı.

Karasar, N. (2005). Bilimsel Araştırma Yöntemi. Ankara: Nobel Yayınevi.

Karkın, G. (2008). Hizmet Pazarlamasının Bir Unsuru Olarak Fiziksel Kanıtlar ve Otel İşletmelerinde Hizmet Atmosferi Oluşturulması, Yayımlanmamış Yüksek Lisans Tezi, İnönü Üniversitesi, Malatya.

Keser, E. (2007). Üniversite Kütüphanelerinde Kullanııı Memnuniyeti Ölçümü, Yüksek Lisans Tezi, İstanbul Üniversitesi, İstanbul.

Kılıçarslan, D. (2016). Ziyaretçi Yönetimi Kapsamında Ziyaretçilerin Atmosfer ve Kalabalık Algılarının Memnuniyet Üzerindeki Etkisinin Tespitine Yönelik Bir Araştırma: Topkapı Sarayı Örneği. Yayımlanmamış Yüksek Lisans Tezi, Akdeniz Üniversitesi, Antalya.

Kotler, P. R., Bowen, J. T. and Makens, J. (2014). Marketing for Hospitality and Tourism. İngiltere: Pearson.

Kotler, P. (1973). Atmospherics as a Marketing Tool, Journal of Retailing, 49(4):48-64.

Kurt, G. (2008). Mağaza Atmosferinin Müşteri Sadakati Oluşturmadaki Rolü: Büyük Ölçekli Gıda Perakendeciliğinde Bir Araştırma, Yayınlanmamış Yüksek Lisans Tezi, Dokuz Eylül Üniversitesi, İzmir. 
Lin, I. Y. (2004). Evaluating a Servicescape: The Effect of Cognition and Emotion, Hospitality Management, 23(2004):163-178.

Motto, M. (1965). R for interior design, Cornell Hospitality Quarterly, 6(3):75-84.

Oliver, R. L. (1980). A Cognitive Model of the Antecedents and Consequences of Satisfaction Decisions, Journal of Marketing Research, 17(4):460-469.

Oliver, R.L. (1999). Whence Consumer Loyalty?, Journal of Marketing, 63(4): 33-44.

Parasuraman, P. A., Zeithaml, V.A. and Berry L.L. (1985). A Conceptual Model of Service Quality and its Implications for Future Research, Journal of Marketing, 49:41-50.

Rızaoğlu, B. (2007). Turizm Pazarlaması. (5. Basım). Ankara: Detay Yayıncılık.

TDK. (2017). Büyük Türkçe Sözlük, http://www.tdk.gov.tr/index.php?option=com_bts\&arama=kelime\&guid=TDK.GTS.5a1ca524d9f 155.47859954> [Erişim Tarihi : 09.02.2017].

Turley, L. W. and Milliman, R. E. (2000). Atmospheric Effects on Shopping Behavior: A Review of the Experimental Evidence, Journal of Business Research, 49(2):193-211.

Varinli, İ. (2005). Marketlerde Pazarlama Yönetimi. Ankara: Detay Yayıncllık.

Zaim, H. ve Tarım, M. (2010). Hasta Memnuniyeti: Kamu Hastaneleri Üzerine Bir Alan Araştırması. Sosyal Siyaset Konferansları. 59(2010/2):1-24.

Zeithaml, V. A., Bitner, M. J. and Gremler, D. D. (2013). Services Marketing: Integrating Customer Focus Across the Firm. (6. Basım.) New York: McGraw-Hill. 
Ek 1. Algılanan Atmosfer Boyutlarının SERVQUAL Boyutlarına Etkisi

\begin{tabular}{|c|c|c|c|c|c|c|c|c|c|c|}
\hline \multirow{2}{*}{\multicolumn{2}{|c|}{ Model }} & \multicolumn{2}{|c|}{$\begin{array}{c}\text { Standartlaştırılmamış } \\
\text { Katsayılar }\end{array}$} & \multirow{2}{*}{$\begin{array}{c}\text { Standartlaşt } \\
\text { 1rılmış } \\
\text { Katsayılar } \\
\text { Beta }\end{array}$} & \multirow[t]{2}{*}{$t$} & \multirow[t]{2}{*}{$\mathrm{p}$} & \multicolumn{2}{|c|}{$\begin{array}{l}\text { ANOVA } \\
\text { Değerleri }\end{array}$} & \multicolumn{2}{|c|}{$\begin{array}{c}\text { Model Özet } \\
\text { Tablosu } \\
\text { Değerleri }\end{array}$} \\
\hline & & B & Std. Hata & & & & $\mathrm{F}$ & $\mathrm{p}$ & $\mathrm{R}$ & $\mathrm{R}^{2}$ \\
\hline \multirow{8}{*}{ 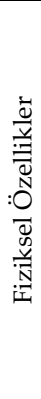 } & (Sabit) & -2.235 & .164 & & -13.638 & .000 & \multirow[t]{2}{*}{108.498} & \multirow[t]{2}{*}{.000} & \multirow[t]{2}{*}{.469} & \multirow[t]{2}{*}{.220} \\
\hline & $\begin{array}{l}\text { Genel içsel ve dişsal } \\
\text { değişkenler }\end{array}$ & .464 & .045 & .469 & 10.416 & .000 & & & & \\
\hline & (Sabit) & -2.235 & .191 & & -12.207 & .000 & \multirow[t]{2}{*}{78.857} & \multirow[t]{2}{*}{.000} & \multirow[t]{2}{*}{.432} & \multirow[t]{2}{*}{.186} \\
\hline & $\begin{array}{l}\text { Düzen ve tasarım } \\
\text { değişkenleri }\end{array}$ & .463 & .049 & .432 & 9.373 & .000 & & & & \\
\hline & (Sabit) & -1.812 & .162 & & -11.170 & .000 & \multirow[t]{2}{*}{61.724} & \multirow[t]{2}{*}{.000} & \multirow[t]{2}{*}{.372} & \multirow[t]{2}{*}{.138} \\
\hline & Kayıt yeri değişkenleri & .347 & .044 & .372 & 7.856 & .000 & & & & \\
\hline & (Sabit) & -1.178 & .219 & & -8.103 & .000 & \multirow[t]{2}{*}{30.800} & \multirow[t]{2}{*}{.000} & \multirow[t]{2}{*}{.272} & .074 \\
\hline & $\begin{array}{l}\text { Çalışanlar ve hijyenle } \\
\text { ilgili değ. }\end{array}$ & .303 & .055 & .272 & 5.550 & .000 & & & & \\
\hline & (Sabit) & -1.389 & .150 & & -9.265 & .000 & 42.479 & .000 & .316 & .100 \\
\hline & $\begin{array}{l}\text { Genel içsel ve dişsal } \\
\text { değişkenler }\end{array}$ & .265 & .041 & .316 & 6.518 & .000 & & & & \\
\hline & (Sabit) & -1.744 & .166 & & -10.489 & .000 & 64.381 & .000 & .379 & .144 \\
\hline :ב & $\begin{array}{l}\text { Düzen ve tasarım } \\
\text { değişkenleri }\end{array}$ & .346 & .043 & .379 & 8.024 & .000 & & & & \\
\hline 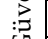 & (Sabit) & -1.415 & .140 & & -10.146 & .000 & 52.367 & .000 & .346 & .120 \\
\hline & Kayıt yeri değişkenleri & .275 & .038 & .346 & 7.237 & .000 & & & & \\
\hline & (Sabit) & -1.501 & .186 & & -8.067 & .000 & 33.674 & .000 & .284 & .081 \\
\hline & $\begin{array}{l}\text { Çalışanlar ve hijyenle } \\
\text { ilgili değ. }\end{array}$ & .268 & .046 & .284 & 5.803 & .000 & & & & \\
\hline & (Sabit) & .179 & .192 & & .928 & .354 & .068 & .794 & .013 & .000 \\
\hline & $\begin{array}{l}\text { Genel içsel ve dişsal } \\
\text { değişkenler }\end{array}$ & -.014 & .052 & -.13 & -.261 & .794 & & & & \\
\hline & (Sabit) & -.212 & .218 & & -.973 & .331 & 2.606 & .107 & .082 & .007 \\
\hline 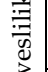 & $\begin{array}{l}\text { Düzen ve tasarım } \\
\text { değişkenleri }\end{array}$ & .091 & .057 & .082 & 1.614 & .107 & & & & \\
\hline 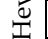 & (Sabit) & -.156 & .181 & & -.865 & .387 & 2.732 & .099 & .084 & .007 \\
\hline & Kayıt yeri değişkenleri & .081 & .049 & .084 & 1.653 & .099 & & & & \\
\hline & (Sabit) & -.391 & .235 & & -1.665 & .097 & 5.164 & .024 & .115 & .013 \\
\hline & $\begin{array}{l}\text { Çalışanlar ve hijyenle } \\
\text { ilgili değ. }\end{array}$ & .133 & .058 & .115 & 2.272 & .024 & & & & \\
\hline & (Sabit) & -.694 & .168 & & -4.126 & .000 & 6.569 & .011 & .130 & .017 \\
\hline & $\begin{array}{l}\text { Genel içsel ve dışsal } \\
\text { değişkenler }\end{array}$ & .117 & .046 & .130 & 2.2563 & .011 & & & & \\
\hline & (Sabit) & -.828 & .191 & & -4.343 & .000 & 8.799 & .003 & .150 & .022 \\
\hline$\sum_{:=}^{\Xi}$ & $\begin{array}{l}\text { Düzen ve tasarım } \\
\text { değişkenleri }\end{array}$ & .147 & .049 & .150 & 2.966 & .003 & & & & \\
\hline 0 & (Sabit) & -.803 & .157 & & -5.112 & .000 & 12.130 & .001 & .175 & .031 \\
\hline & Kayıt yeri değişkenleri & .149 & .043 & .175 & 3.483 & .001 & & & & \\
\hline & (Sabit) & -.795 & .207 & & -3.848 & .000 & 6.566 & .011 & .130 & .017 \\
\hline & $\begin{array}{l}\text { Çalışanlar ve hijyenle } \\
\text { ilgili değ. }\end{array}$ & .131 & .051 & .130 & 2.562 & .011 & & & & \\
\hline & (Sabit) & -.034 & .223 & & -.151 & .880 & 1.931 & .165 & .071 & .002 \\
\hline & $\begin{array}{l}\text { Genel içsel ve dışsal } \\
\text { değişkenler }\end{array}$ & .084 & .061 & .071 & 1.390 & .165 & & & & \\
\hline & (Sabit) & -0.27 & .254 & & -.106 & .916 & 1.399 & .238 & .060 & .004 \\
\hline : & $\begin{array}{l}\text { Düzen ve tasarım } \\
\text { değişkenleri }\end{array}$ & .078 & .066 & .060 & 1.183 & .238 & & & & \\
\hline 武 & (Sabit) & -.111 & .210 & & -.530 & .596 & 3.499 & .062 & .095 & .009 \\
\hline & Kayıt yeri değişkenleri & .107 & .057 & .095 & 1.871 & .062 & & & & \\
\hline & (Sabit) & -.147 & .274 & & -.538 & .591 & 2.380 & .124 & .078 & .006 \\
\hline & $\begin{array}{l}\text { Çalışanlar ve hijyenle } \\
\text { ilgili değ. }\end{array}$ & .105 & .068 & .078 & 1.543 & .124 & & & & \\
\hline
\end{tabular}

